\title{
Prevalence and Associated Factors with Mixed Coinfections among under 5-Year-Old Children with Severe Viral Pneumonia in Vietnam
}

\author{
Hien T. Pham ${ }^{1}$ Tran N. T. Nguyen ${ }^{2}$ Quynh A. Tran 3 \\ ${ }^{1}$ International Outpatient Department, National Children's Hospital, \\ Hanoi, Vietnam \\ 2 Respiratory Department, National Children's Hospital, Hanoi, Vietnam \\ ${ }^{3}$ Surgical Department, National Children's Hospital, Hanoi, Vietnam \\ ${ }^{4}$ Faculty of Health Sciences, Thang Long University, Hanoi, Vietnam
}

\author{
Tam T. $\mathrm{Ngo}^{4(1)}$
}

Address for correspondence Tam T. Ngo, Mcs, Faculty of Health Sciences, Thang Long University, Hanoi, Vietnam 100000 (e-mail: ngothitam.tlu@gmail.com).

J Child Sci 2020;10:e74-e79.

\begin{abstract}
Community-acquired pneumonia (CAP) is well-recognized as a leading cause of disease burden in children. This study aimed to identify the prevalence of coinfection and associated factors in Vietnamese children ages 1 month to 5 years with viral pneumonia. We performed a cross-sectional study of children who were diagnosed with severe viral pneumonia. Demographic, clinical, and subclinical characteristics were compared between children with viral alone and bacterial coinfection. Multivariate logistic regression was used to determine which factors were associated with risk of coinfection. Of 202 children with severe viral pneumonia, the most common causative agent was respiratory syncytial virus (respiratory syncytial virus [RSV]: 36.1\%), followed by influenza virus A (24.3\%) and adenovirus (19.8\%). Fifty-three children (26.2\%) had bacterial superinfection and/or coinfection with other viruses. Haemophilus influenza was the most common bacterium (9.4\%), followed by Klebsiella pneumoniae and Pseudomonas aeruginosa (with 4.0\%). In infants (toddlers), ages 12 to 24 months with severe viral pneumonia, (odds ratio $[\mathrm{OR}]=3.37$, 95\% confidence interval $[\mathrm{Cl}]: 1.22-9.33)$, the higher concentrations of procalcitonin ( $\mathrm{PCT} ; \mathrm{OR}=1.16 ; 95 \% \mathrm{Cl}$ : $1.00-1.34$ ), and neutrophils ( $\mathrm{OR}=1.13 ; 95 \% \mathrm{Cl}$ :

\section{Keywords}

- bacterial

- viral

- severe pneumonia

- coinfection 1.04-1.22) were associated with a higher risk of coinfection. This study underlined the pervasiveness of coinfections among young children with severe viral pneumonia. Provision of effective antiviral treatment, especially for RSV, as well as the advancement of sensitive and rapid diagnostic tools for screening pathogens of pneumonia, is critical to reducing the burden of this disease.
\end{abstract}

\section{Key Messages}

This study underlined the pervasiveness of coinfections among young children with severe viral pneumonia. Provision of effective antiviral treatment, especially for respiratory syncytial virus (RSV), as well as the advancement of sensitive and rapid diagnostic tools for screening pathogens of pneumonia, is critical to reducing the burden of this disease.
DOI https://doi.org/

10.1055/s-0040-1713623. ISSN 2474-5871.

\section{Introduction}

Globally, community-acquired pneumonia (CAP) has been well-recognized as a leading cause of disease burden in children under 5 years. CAP is responsible for approximately 2 million infant deaths annually. ${ }^{1,2}$ However, the management of this disease in the hospital still faces a significant challenge due to critical knowledge gaps about the etiology and clinical manifestations of CAP in young children. ${ }^{3}$

Copyright $\odot 2020$ Georg Thieme Verlag License terms KG Stuttgart · New York

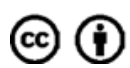


Viruses have been identified as the most common causes of CAP, with bacterial pneumonia being less common. ${ }^{1,3,4}$ Typical viruses include respiratory syncytial virus (RSV), ${ }^{5}$ rhinovirus, influenza virus, and adenovirus. However, there are usually no specific clinical symptoms to definitively diagnose the specific type of virus. Moreover, recent advanced molecular techniques confirm the pervasiveness of virus-virus and virus-bacterium coinfections. ${ }^{6-8}$ Previous work figured out that approximately 14 to $35 \%$ of infants with CAP suffered coinfections. ${ }^{6-10}$ Younger age, admission to an intensive care unit, and comorbidity are significant predictors of coinfection conditions. $4,11,12$

In Vietnam, the number of children with pneumonia accounts for 30 to $40 \%$ of cases of medical examination and treatment in hospitals. ${ }^{13}$ Additionally, $75 \%$ of deaths due to respiratory diseases and 30 to $35 \%$ of deaths among children. ${ }^{13}$ Studies of pneumonia in Vietnamese children have been performed previously ${ }^{14-16}$; however, evidence about coinfections and their risk factors has not been thoroughly investigated. This study aims to identify the prevalence of coinfection and associated factors Vietnamese children under 5 years with viral pneumonia.

\section{Patients and Methods}

\section{Study Designs}

A cross-sectional study was conducted of 202 children with severe viral pneumonia who treated at the National Hospital of Pediatrics from January 2015 to March 2017,according to World Health Organizations (WHO)-2013 standards. ${ }^{17}$ Severe cases of viral pneumonia were defined as follows: (1) having cough or difficulty breathing; (2) finding viruses in nasal fluid, phlegm, or sputum; and at least one of the following main symptoms: (1) cyanosis or $\mathrm{SpO}_{2}<90 \%$, (2) severe respiratory distress (moaning and intercostal muscle external retraction), (3) inability to tolerate enteral fluids, (4) loss of consciousness or coma, and/or (5) convulsions.

We excluded children who (1) age below 1 month or above 5 years; (2) had nonviral pneumonia (for example pneumonia after drowning, chemical pneumonia, aspiration pneumonia); (3) had chronic, associated congenital diseases, or not (e.g., airway malformation, congenital lung disease, liver failure, kidney failure, cystic fibrosis, chronic granulomatous disease, or immune deficiency); or (4) were eligible to participate in the study but the parents or guardian did not agree to participate. This study was approved by the Institutional Review Board of Vietnam Military Medical University (Code: 92/QĐ-HVQY, January 21, 2015).

\section{Data Collection}

All participants after hospitalization were carefully examined clinical symptoms by pediatrics. Demographic information and medical history were collected from parents or guardians. The specimens were collected and sent to the laboratory within the first 1 hour, refrigerated, and performed at the Department of Molecular Biology, National Hospital of Pediatrics. Also, participants underwent one laboratory draw for several tests, including complete blood counts, interleukin (IL)-6, high-sensitivity C-reactive protein (hsCRP), and procalcitonin (PCT).

\section{Specimen Collection and Blood Tests}

One milliliter of vascular blood was taken into the tube with ethylenediaminetetraacetic (EDTA) upon hospitalization for hematological tests. The tests were run by ABX Micros ES60. Meanwhile, biochemical tests were conducted by taking $2 \mathrm{~mL}$ of venous blood when the patient was hospitalized, does not freeze, centrifuge, and is done. Specimens were put into tubes without anticoagulants or with anticoagulants such as Li-Heparin and K3-EDTA. After drawing blood, specimens were centrifuged to extract serum or plasma. The level of hsCRP was determined via turbidity measurement using the Olympus AU 2700 machine. PCT concentration was measured via the luminescent immunization method using the ADVIA Centaur machine of Siemens company. Meanwhile, IL-6 was measured by using BioRad's Bio-Plex Protein Array System.

\section{Viral Detection}

Influenza virus A, influenza virus B, and RSV were detected via rapid tests that used the immunochromatographic method. Rhinovirus and adenovirus were identified by utilizing the real-time polymerase chain reaction (RT-PCR). Each patient received $1 \mathrm{~mL}$ of blood and $2 \mathrm{~mL}$ of nasopharyngeal fluid upon admission. Samples collected were sent to the laboratory within the first hour, refrigerated, and tested. The RT-PCR method was conducted on RT-PCR ABI 7500 and ABI 7500 FAST machines, following the procedure of the Department of Molecular Biology, National Hospital of Pediatrics.

Samples of respiratory fluid collected were used for total RNA/DNA extraction (MagNA Pure LC Total Nucleic acid Isolation Kit, Roche) on MagNA Pure LC 2.0 automatic extraction system (Roche). The forward primers were: GCC ACG GTG GGG TTT CTA AAC TT, the reverse primers were GCC CCA GTG GTC TTA CATGCA CT C, and the probe sequences were carboxyfluorescein (FAM), TGC ACC AGA CCC GGG CTC AGG TAC TCC GA, tetramethyl-6-carboxyrhodamine (TAMRA). Reaction components include: $0.625 \mu \mathrm{L}$ concentration of $10 \mathrm{pM}$ of each primer; $0.5 \mu \mathrm{L}$ concentration of 10 pM probe; $12.5 \mu \mathrm{L} 2$ X PCR master mix (Qiagen); $5 \mu \mathrm{L}$ DNA and $\mathrm{H}_{2} \mathrm{O}$, which were added in total reaction of $25 \mu \mathrm{L}$. Reaction program included: 500-2 minutes, 950-15 minutes, and 45 cycles of 950-15 seconds, and 580-1 minute. RT-PCR assays for Adenovirus detection used oligonucleotide primers and dual-labeled hydrolysis probes (Taqman). The estimated time for running samples was approximately 125 minutes. The positive control was from the plasmid of Gothenburg University, Sweden, and the negative control was the water component in the PCR reaction mixture. Results were read and analyzed using a RT ABI 7500 Fast system.

\section{Bacterial Detection}

Bacterial testing was performed by the Vitek-2 machine. The bacterium was detected by using the colorimetric method to identify the chemical, biological properties of each bacteria via color change of environmental wells in the card. Moreover, an antibiotic method was also utilized by using the minimum inhibitory concentration measurement method, 
which measured turbidity to monitor the development of microorganisms in the card wells. These two methods were performed according to the principle of light intensity reduction. The system used wavelength 660, 568, and 428 .

\section{Statistical Analysis}

Chi-squared and Kruskal-Wallis tests were utilized to compare demographic, clinical, and paraclinical characteristics between children with pneumonia caused by one virus only versus those in which more than one virus was identified (viral coinfection) and versus those in which bacterial superinfection occurred. STATA software 15.0 was used to analyze data. Multivariate logistic regression was performed to identify the associated factors with mixed coinfections. A stepwise backward selection strategy was used, using the $p$ value of a log-likelihood test of less than 0.2 as a threshold to select variables. A two-tailed $p$-value of less than 0.05 was considered statistically significant.

\section{Results}

Of 202 children with severe viral pneumonia, overall, the mean age of patients was 8.6 months (standard deviation $[S D]=9.6$, range: $1.0-48.7$ months). Among them, $59.9 \%$ of study participants were male. Also, there was $19.8 \%$ of children were born with low birth weight, $19.8 \%$ were born premature, $52 \%$ suffered from malnutrition, and $25.7 \%$ were not fully. - Table 1 shows that the majority of patients had RSV (36.1\%), followed by influenza virus A (24.3\%) and adenovirus (19.8\%). There were 53 children (26.2\%) coinfected with bacteria or/and other viruses.

- Table 2 illustrated that among children with bacteria superinfection, the incidence of Haemophilus influenza was the highest (45.2\%), followed by Klebsiella pneumoniae and Pseudomonas aeruginosa (with 19.1\%).

The distribution of coinfection status, according to sociodemographic characteristics, is depicted in - Table 3. No difference was found among these coinfection conditions regarding age, gender, new-born weight, nutritional status, and immunization status ( $p>0.05)$.

Clinical characteristics of different coinfection conditions are shown in - Table 4. Fever, cyanosis, and not hepatosplenomegaly were significantly different across groups $(p<0.05)$.
Table 2 Type of bacterium among viral pneumonia children with coinfections

\begin{tabular}{|l|l|l|l|}
\hline Type of bacterium & $n$ & $\begin{array}{l}\text { Children with } \\
\text { bacterial } \\
\text { coinfections } \\
(\%)\end{array}$ & $\begin{array}{l}\text { Percentage } \\
\text { in entire } \\
\text { sample }\end{array}$ \\
\hline Haemophilus influenza & 19 & 45.2 & 9.4 \\
\hline Klebsiella pneumoniae & 8 & 19.1 & 4.0 \\
\hline Pseudomonas aeruginosa & 8 & 19.1 & 4.0 \\
\hline Streptococcus pneumoniae & 7 & 16.7 & 3.5 \\
\hline Acinetobacter baumannii & 4 & 9.5 & 2.0 \\
\hline Burkholderia cepacia & 1 & 2.4 & 0.5 \\
\hline Staphylococcus aureus & 1 & 2.4 & 0.5 \\
\hline
\end{tabular}

The total white blood cell count, neutrophils cell count, concentration of hsCRP, and PCT were significantly higher in patients with bacterial coinfections or bacterial and viral coinfections $(p<0.05)$.Invasive mechanical ventilation was significantly pervasive in infants with both bacterial and viral coinfections $(p<0.05)$. They also had a significantly higher length of stay compared with other groups $(p<0.05)$.

The multivariate regression model showed that in toddlers ages 12 to 24 months with severe viral pneumonia (odds ratio $[\mathrm{OR}]=3.37,95 \%$ confidence interval $[\mathrm{CI}]: 1.22-$ 9.33), the higher concentration level of PCT (OR $=1.16 ; 95 \%$ CI: $1.00-1.34$ ), and neutrophils ( $\mathrm{OR}=1.13 ; 95 \% \mathrm{CI}: 1.04-$ 1.22 ) were associated with a higher risk of suffering from any type of coinfection (-Table 5 ).

\section{Discussion}

This study contributes to global literature regarding the etiology and clinical characteristics of severe viral pneumonia among infants in Vietnam. Results indicated that RSV and influenza virus A was the most common viral pathogens, and one-fifth of patients identified coinfections. Age and level of PCT and Neutrophils were important markers to predict coinfection conditions.

The pattern of viral pathogens in the current study differs from other previous studies. In Pakistan, a study of 817 infants and children under 2 years of age showed that the prevalence

Table 1 Etiology of viral pneumonia

\begin{tabular}{|c|c|c|c|c|c|}
\hline \multirow[t]{2}{*}{ Characteristics } & $\begin{array}{l}\text { Single virus } \\
(n=149)\end{array}$ & $\begin{array}{l}\text { Coinfection with } \\
\text { bacteria }(n=34)\end{array}$ & $\begin{array}{l}\text { Coinfection with } \\
\text { virus }(n=11)\end{array}$ & $\begin{array}{l}\text { Coinfection with } \\
\text { bacteria and } \\
\text { virus }(n=8)\end{array}$ & Total $(n=202)$ \\
\hline & $n(\%)$ & $n(\%)$ & $n(\%)$ & $n(\%)$ & $n(\%)$ \\
\hline Influenza virus A & $36(73.5)$ & $5(10.2)$ & $6(12.2)$ & $2(4.1)$ & $49(24.3)$ \\
\hline Influenza virus B & $10(71.4)$ & $4(28.6)$ & $0(0.0)$ & $0(0.0)$ & $14(6.9)$ \\
\hline RSV & $59(80.8)$ & $11(15.1)$ & $2(2.7)$ & $1(1.4)$ & $73(36.1)$ \\
\hline Adenovirus & $28(70.0)$ & $7(17.5)$ & $3(7.5)$ & $2(5.0)$ & $40(19.8)$ \\
\hline Rhinovirus & $16(61.5)$ & $7(26.9)$ & $0(0.0)$ & $3(11.5)$ & $26(12.9)$ \\
\hline
\end{tabular}

Abbreviation: RSV, respiratory syncytial virus. 
Table 3 Patients' characteristics according to coinfection status

\begin{tabular}{|c|c|c|c|c|c|}
\hline \multirow[t]{2}{*}{ Characteristics } & $\begin{array}{l}\text { Single virus } \\
(n=149)\end{array}$ & $\begin{array}{l}\text { Coinfection with } \\
\text { bacteria }(n=34)\end{array}$ & $\begin{array}{l}\text { Coinfection with } \\
\text { virus }(n=11)\end{array}$ & $\begin{array}{l}\text { Coinfection with bacteria } \\
\text { and virus }(n=8)\end{array}$ & \multirow[t]{2}{*}{$p$-Value } \\
\hline & $n(\%)$ & $n(\%)$ & $n(\%)$ & $n(\%)$ & \\
\hline \multicolumn{6}{|l|}{ Age group (mo) } \\
\hline $0-6$ & $88(76.5)$ & $16(13.9)$ & $6(5.2)$ & $5(4.4)$ & \multirow[t]{4}{*}{0.19} \\
\hline$>6-12$ & $31(77.5)$ & $8(20.0)$ & $0(0.0)$ & $1(2.5)$ & \\
\hline$>12-24$ & 14 (51.9) & $8(29.6)$ & $3(11.1)$ & $2(7.4)$ & \\
\hline$>24$ & $16(80.0)$ & $2(10.0)$ & $2(10.0)$ & $0(0.0)$ & \\
\hline \multicolumn{6}{|l|}{ Gender } \\
\hline Female & $63(77.8)$ & $13(16.1)$ & $2(2.5)$ & $3(3.7)$ & \multirow[t]{2}{*}{0.46} \\
\hline Male & $86(71.1)$ & $21(17.4)$ & $9(7.4)$ & $5(4.1)$ & \\
\hline \multicolumn{6}{|l|}{ Birth weight (g) } \\
\hline$<2,500$ & $26(65.0)$ & $9(22.5)$ & $2(5.0)$ & $3(7.5)$ & \multirow[t]{2}{*}{0.38} \\
\hline$\geq 2,500$ & $123(75.9)$ & $25(15.4)$ & $9(5.6)$ & $5(3.1)$ & \\
\hline \multicolumn{6}{|l|}{ Nutritional status } \\
\hline Normal & $51(75.0)$ & $11(16.2)$ & $5(7.4)$ & $1(1.5)$ & \multirow[t]{3}{*}{0.65} \\
\hline Malnutrition & $75(71.4)$ & $18(17.1)$ & $6(5.7)$ & $6(5.7)$ & \\
\hline Overweight/obesity & $23(79.3)$ & $5(17.2)$ & $0(0.0)$ & $1(3.5)$ & \\
\hline \multicolumn{6}{|l|}{ Immunization } \\
\hline Full & $114(76.0)$ & $26(17.3)$ & $7(4.7)$ & $3(2.0)$ & \multirow[t]{2}{*}{0.08} \\
\hline Missing & $35(67.3)$ & $8(15.4)$ & $4(7.7)$ & $5(9.6)$ & \\
\hline
\end{tabular}

of enterovirus/rhinovirus infection was $51.7 \%$, followed by influenza viruses (8.3\%) and RSV (5.7\%). ${ }^{18}$ A study in China showed that the most common causative viruses were enterovirus/rhinovirus (54.1) \%), RSV (51.1\%), Human bocavirus (33.8\%), parainfluenza viruses type 3 (PIV3; 15.4\%), and adenovirus (ADV; $13.0 \%$ ). ${ }^{19}$ Another study in China indicated a similar finding with our study that RSV was the most common pathogen ${ }^{4}$ which was consistent with other studies in the United States of America ${ }^{7}$ and Spain. ${ }^{20}$

Coinfection was common among children with severe viral pneumonia in our study, approximately $25.3 \%$ of our patients experienced coinfection in any type. This rate was a slightly lower than that reported in previous studies in China and the United States, which found that $34.6 \%$ of infants with CAP suffering from coinfections, ${ }^{4,21}$ but was similar to another nationally representative study in the United States, which indicated that $26 \%$ had coinfections. ${ }^{7}$ Pavia et al found that among 58 pediatric patients with pneumonia, 35\% were coinfected. ${ }^{22}$ Nascimento-Carvalho et al in a group of 25 pneumonia children with pleural effusion, showed that $22 \%$ of cases had viral-bacterial coinfections. ${ }^{23}$ Juvén et al indicated that approximately $30 \%$ of cases suffered from viral-bacterial coinfections. ${ }^{24}$ Moreover, the study results showed that the incidence of $H$. influenza was the highest (9.4\% of the entire sample), followed by K. pneumoniae and $P$. aeruginosa (with $4.0 \%$ of the entire sample). Streptococcus pneumoniae had been found in $3.5 \%$ of the sample, which was consistent with prior studies in China (3.0\%) and the United States (4\%). ${ }^{4,7}$ However, $9.4 \%$ of our study population were infected with another virus, which was much lower compared with the previous study in the United States (26.0\%). ${ }^{7}$ The disparities might be attributable to the seasonal or geographical factors.

The results of this study showed that the majority of clinical characteristics could not distinguish between coinfection groups except fever, cyanosis, hepatosplenomegaly, and invasive mechanical ventilation. Similarly, analysis of paraclinical indicators indicated that the total white blood cell count, neutrophils cell count, concentration of hsCRP, and PCT were significantly higher among infants with bacterial superinfection versus single virus. This result was in line with prior study in the United States, which revealed that the prevalence of fever, as well as the level of neutrophils, were the lowest among patients having viral infections only or viral coinfections. ${ }^{21}$ Similarly, the study in China found that infants with mixed infections had a higher rate of fever than that of patients who were infected with a single virus. ${ }^{4}$ We conjecture that pediatric patients having viral coinfections presented a higher level of inflammation than those having an only single viral infection. ${ }^{4}$ Additionally, the regression model confirmed the associations between PCT and neutrophils with mixed coinfections after adjusting to other covariates, suggesting potential biomarkers to predict coinfections among young children with severe viral pneumonia.

\section{Limitations}

This study had several limitations. The study was conducted at the hospital; therefore, the results of the study were only 
e78 Cross-Sectional Study of Children with Severe Viral Pneumonia Pham et al.

Table 4 Clinical characteristics regarding coinfection status

\begin{tabular}{|c|c|c|c|c|c|}
\hline Characteristics & $\begin{array}{l}\text { Single virus } \\
(n=149)\end{array}$ & $\begin{array}{l}\text { Coinfection with } \\
\text { bacteria }(n=34)\end{array}$ & $\begin{array}{l}\text { Coinfection with } \\
\text { virus }(n=11)\end{array}$ & $\begin{array}{l}\text { Coinfection with bacteria } \\
\text { and virus }(n=8)\end{array}$ & $p$-Value \\
\hline & $n(\%)$ & $n(\%)$ & $n(\%)$ & $n(\%)$ & \\
\hline Fever & $100(67.1)$ & $30(88.2)$ & $10(90.9)$ & $6(75.0)$ & 0.04 \\
\hline Rapid heart pulse & $80(53.7)$ & $20(58.8)$ & $10(90.9)$ & $4(50.0)$ & 0.11 \\
\hline Runny nose & $61(40.9)$ & $14(41.2)$ & $4(36.4)$ & $1(12.5)$ & 0.45 \\
\hline Wheezing & $125(83.9)$ & $29(85.3)$ & $9(81.8)$ & $6(75.0)$ & 0.91 \\
\hline Grunting & $9(6.0)$ & $1(2.9)$ & $2(18.2)$ & $2(25.0)$ & 0.07 \\
\hline Poor feeding & $117(78.5)$ & $23(67.7)$ & $10(90.9)$ & $8(100.0)$ & 0.14 \\
\hline Excessive crying & $36(24.2)$ & $11(32.4)$ & $1(9.1)$ & $4(50.0)$ & 0.17 \\
\hline Convulsions & $9(6.0)$ & $0(0.0)$ & $1(9.1)$ & $1(12.5)$ & 0.37 \\
\hline Cyanosis & $35(23.5)$ & $7(20.6)$ & $5(45.5)$ & $8(100.0)$ & $<0.01$ \\
\hline Diarrhea & $44(29.5)$ & $11(32.4)$ & $1(9.1)$ & $1(12.5)$ & 0.34 \\
\hline No hepatosplenomegaly & $138(92.6)$ & $30(88.2)$ & $8(72.7)$ & $5(62.5)$ & 0.01 \\
\hline \multirow[t]{2}{*}{ Invasive mechanical ventilation } & $11(7.4)$ & $7(21.2)$ & $2(18.2)$ & $5(62.5)$ & $<0.01$ \\
\hline & Mean (SD) & Mean (SD) & Mean (SD) & Mean (SD) & \\
\hline Time from illness onset to admission (d) & $7.2(6.6)$ & $5.9(4.8)$ & $5.5(3.9)$ & $7.6(5.2)$ & 0.93 \\
\hline Length of stay (d) & $13.2(13.6)$ & $23.4(33.1)$ & $17.4(14.5)$ & $33.5(22.3)$ & $<0.01$ \\
\hline Hemoglobin $(\mathrm{g} / \mathrm{dL})$ & $105.2(14.3)$ & $105.2(13.4)$ & $105.5(8.5)$ & $94.6(9.6)$ & 0.13 \\
\hline White blood cell (G/L) & $11.1(5.1)$ & $14.8(7.7)$ & $9.1(2.8)$ & $14.4(6.2)$ & $<0.01$ \\
\hline Neutrophils (G/L) & $4.7(3.6)$ & $8.3(6.4)$ & $4.1(1.8)$ & $7.9(5.2)$ & $<0.01$ \\
\hline Lymph (G/L) & $4.7(2.6)$ & $4.6(2.4)$ & $3.3(1.2)$ & $5.1(2.5)$ & 0.30 \\
\hline Mono (G/L) & $1.3(1.1)$ & $1.5(1.0)$ & $1.2(0.7)$ & $1.3(0.6)$ & 0.72 \\
\hline Platelet (G/L) & $382.6(155.6)$ & $417.7(230.1)$ & $324.7(163.8)$ & 437.1 (190.9) & 0.42 \\
\hline hsCRP (mg/dL) & $12.7(25.6)$ & $32.5(51.8)$ & $8.1(10.8)$ & $9.3(10.6)$ & 0.02 \\
\hline PCT (ng/mL) & $1.1(1.7)$ & $3.4(5.9)$ & $0.8(1.1)$ & $6.8(15.1)$ & $<0.01$ \\
\hline IL-6 (pg/mL) & $26.0(82.1)$ & $22.1(36.9)$ & $13.8(12.4)$ & 98.9 (171.1) & 0.13 \\
\hline
\end{tabular}

Abbreviations: hsCRP, high sensitivity C-reactive protein; IL-6, interleukin-6; PCT, procalcitonin; SD, standard deviation.

Table 5 Associated factors with mixed coinfections

\begin{tabular}{|c|c|c|c|c|}
\hline \multirow[t]{2}{*}{ Factor } & \multicolumn{4}{|c|}{ Mixed coinfection (yes/no) } \\
\hline & OR & $p$ & $95 \% \mathrm{Cl}$ & \\
\hline \multicolumn{5}{|l|}{ Age group (mo) } \\
\hline $0-6$ & REF & & & \\
\hline$>6-12$ & 0.90 & 0.84 & 0.32 & 2.49 \\
\hline$>12-24$ & 3.37 & 0.02 & 1.22 & 9.33 \\
\hline$>24$ & 1.02 & 0.97 & 0.27 & 3.83 \\
\hline \multicolumn{5}{|l|}{ Immunization } \\
\hline Full injection & REF & & & \\
\hline Missing injection & 2.02 & 0.11 & 0.86 & 4.73 \\
\hline \multicolumn{5}{|l|}{ Cyanosis } \\
\hline No & REF & & & \\
\hline Yes & 2.08 & 0.07 & 0.93 & 4.63 \\
\hline \multicolumn{5}{|c|}{ No hepatosplenomegaly } \\
\hline No & REF & & & \\
\hline Yes & 0.38 & 0.06 & 0.14 & 1.06 \\
\hline PCT (ng/mL) & 1.16 & 0.045 & 1.00 & 1.34 \\
\hline Neutrophil (G/L) & 1.13 & $<0.01$ & 1.04 & 1.22 \\
\hline
\end{tabular}

Abbreviation: $\mathrm{Cl}$, confidence interval; OR, odds ratio; $\mathrm{PCT}$, procalcitonin; REF, reference. 
conclusive for the pneumonia children treated at the National Hospital of Pediatrics, and we could not extrapolate to the community. Our sample size was small and conveniently recruited, which thus might reduce our generalizability. Moreover, data on several variables in the study, such as nutritional status and premature birth, were significantly high or not allowed to categorize into more details. The cross-sectional design is a limitation because of its limitations due to its nature.

\section{Conclusion}

To conclude, this study underlined the pervasiveness of coinfections among infants and young children with severe viral pneumonia. Provision of effective antiviral treatment, especially for RSV, as well as the advancement of sensitive and rapid diagnostic tools for screening pathogens of pneumonia, is critical to reducing the burden of this disease.

\section{Conflicts of Interest}

None declared.

\section{References}

1 Rudan I, Boschi-Pinto C, Biloglav Z, Mulholland K, Campbell H. Epidemiology and etiology of childhood pneumonia. Bull World Health Organ 2008;86(05):408-416

2 Nair H, Simões EA, Rudan I, et al; Severe Acute Lower Respiratory Infections Working Group. Global and regional burden of hospital admissions for severe acute lower respiratory infections in young children in 2010: a systematic analysis. Lancet 2013;381 (9875):1380-1390

3 Bradley JS, Byington CL, Shah SS, et al; Pediatric Infectious Diseases Society and the Infectious Diseases Society of America. Executive summary: the management of community-acquired pneumonia in infants and children older than 3 months of age: clinical practice guidelines by the Pediatric Infectious Diseases Society and the Infectious Diseases Society of America. Clin Infect Dis 2011;53(07):617-630

4 Jiang W, Wu M, Zhou J, et al. Etiologic spectrum and occurrence of coinfections in children hospitalized with community-acquired pneumonia. BMC Infect Dis 2017;17(01):787

5 Son BBB. Studying blood procalcitonin concentration in children from 2 months - 5 years old with pneumonia. Medical J Ho Chi Minh City 2007;11(04):36-41

6 Honkinen M, Lahti E, Osterback R, Ruuskanen O, Waris M. Viruses and bacteria in sputum samples of children with communityacquired pneumonia. Clin Microbiol Infect 2012;18(03):300-307

7 Jain S, Williams DJ, Arnold SR, et al; CDC EPIC Study Team. Community-acquired pneumonia requiring hospitalization among U.S. children. N Engl J Med 2015;372(09):835-845

8 Wei L, Liu W, Zhang XA, et al. Detection of viral and bacterial pathogens in hospitalized children with acute respiratory illnesses, Chongqing, 2009-2013. Medicine (Baltimore) 2015;94(16):e742
9 Cilla G, Oñate E, Perez-Yarza EG, Montes M, Vicente D, PerezTrallero E. Viruses in community-acquired pneumonia in children aged less than 3 years old: High rate of viral coinfection. J Med Virol 2008;80(10):1843-1849

10 Wang XF, Liu JP, Shen KL, et al. A cross-sectional study of the clinical characteristics of hospitalized children with communityacquired pneumonia in eight eastern cities in China. BMC Complement Altern Med 2013;13:367

11 Thorburn K, Harigopal S, Reddy V, Taylor N, van Saene HK. High incidence of pulmonary bacterial co-infection in children with severe respiratory syncytial virus (RSV) bronchiolitis. Thorax 2006;61(07):611-615

12 Zhang X, Chen Z, Gu W, et al. Viral and bacterial co-infection in hospitalised children with refractory Mycoplasma pneumoniae pneumonia. Epidemiol Infect 2018;146(11):1384-1388

13 Quu T, Van TTH. Bronchopneumonia. Medical publishers: Hanoi Medical University; 2013

14 Nguyen PTK, Tran HT, Fitzgerald DA, Tran TS, Graham SM, Marais BJ. Characterisation of children hospitalised with pneumonia in central Vietnam: a prospective study. Eur Respir J 2019;54(01): 1802256

15 Le P, Griffiths UK, Anh DD, et al. The economic burden of pneumonia and meningitis among children less than five years old in Hanoi, Vietnam. Trop Med Int Health 2014;19(11): 1321-1327

16 Huong PleT, Hien PT, Lan NT, Binh TQ Tuan DM, Anh DD. First report on prevalence and risk factors of severe atypical pneumonia in Vietnamese children aged 1-15 years. BMC Public Health 2014; $14: 1304$

17 WHO. Guidelines for the management of common childhood illnesses 2nd ed. Available at: https://apps.who.int/iris/bitstream/ handle/10665/81170/9789241548373_eng.pdf;jsessionid=64EB3 417C6927C04E5EBA2290FE16DF1? sequence $=1$. Accessed May 26, 2020

18 Ali A, Akhund T, Warraich GJ, et al. Respiratory viruses associated with severe pneumonia in children under 2 years old in a rural community in Pakistan. J Med Virol 2016;88(11):1882-1890

19 Zhang C, Zhu N, Xie Z, et al. Viral etiology and clinical profiles of children with severe acute respiratory infections in China. PLoS One 2013;8(08):e72606

20 García-García ML, Calvo C, Pozo F, Villadangos PA, Pérez-Breña P, Casas I. Spectrum of respiratory viruses in children with community-acquired pneumonia. Pediatr Infect Dis J 2012;31(08): 808-813

21 Michelow IC, Olsen K, Lozano J, et al. Epidemiology and clinical characteristics of community-acquired pneumonia in hospitalized children. Pediatrics 2004;113(04):701-707

22 Pavia AT. Viral infections of the lower respiratory tract: old viruses, new viruses, and the role of diagnosis. Clin Infect Dis 2011;52(Suppl 4):S284-S289

23 Nascimento-Carvalho CM, Oliveira JR, Cardoso M-RA, et al. Respiratory viral infections among children with community-acquired pneumonia and pleural effusion. Scand J Infect Dis 2013; 45(06):478-483

24 Juvén T, Mertsola J, Waris M, et al. Etiology of communityacquired pneumonia in 254 hospitalized children. Pediatr Infect Dis J 2000;19(04):293-298 